\title{
Elements of Infrastructure: Factors Driving International Entrepreneurship
}

\author{
Stephen K. Callaway
}

T

This article focuses on "born globals" (Knight and Cavusgil 1996) and interfirm resources to explain international entrepreneurship. The theory posed here challenges the traditional image of international business as a long, gradual process not occurring until later in the life cycle, and applying only to large multinational corporations (MNCs).

Increasingly, new ventures must expand their operations internationally early in their history in order to be competitive (Oviatt and McDougall 1994), and require infrastructure (Van de Ven 1993), or interfirm resources, for success. Specifically, firms may rely on three factors to expand internationally: cost factors, unique global resources, and networks.

Traditional theories of international business (IB) view the global expansion of companies as a long, gradual process not occurring until later in the life cycle, focus predominately on large multinational companies (MNCs) as opposed to entrepreneurial start-ups, or focus on firm-specific ownership or internalization advantages. As a result, theories explaining rapid internationalization, the international expansion of entrepreneurial ventures, or advantages arising from global networks, have been scarce.

Many traditional IB theories focus on how market demand drives international expansion. For example, some theories argue that entrepreneurs respond to local market demand, then expand internationally when the domestic market becomes saturated; that is, export is the end, not the beginning of a typical market expansion path (Linder 1961). Entrepreneurs are not likely to bear the necessary costs of investigating overseas markets of unknown dimensions and unknown promise (Vernon 1966). Furthermore, internationalization theory argues that firms expand into international markets slowly over time, initially entering markets that are most familiar (most similar) to the home market (Johanson and Vahlne 1977).

Further, the motivation for international expansion has generally been viewed as stemming from firm-specific ownership advantages, which can be extended to foreign markets, and that are best internalized within the firm because of transaction costs (Dunning 1988). However, the increasing prevalence of networks, alliances, public goods, and industry-wide standards has provided important resources to clusters of firms, including entrepreneurial start-ups. That is, many advantages are no longer firm specific (Dunning 1995).

As a result, these traditional theories of internationalization have received increasing criticism in recent years. First, innovation and technical change (Posner 1961) have long been recognized as major drivers of export behavior. Many emerging high-technology industries increasingly demonstrate the importance of this catalyst. Second, more entrepreneurial ventures show substantial international operations. Nowadays, increasingly firms must expand their operations internationally early in their history in order to be competitive (Oviatt and McDougall 1994). Such firms have been labeled "instant internationals" (Hordes, Clancy, and Baddaley 1995) or "born global" (Knight and Cavusgil 1996).

Similarly, Bell et al. (2003) found evidence of "bornglobals" as well as firms suddenly internationalizing after a long period of focusing on the domestic market. However, while traditional IB theories have not addressed this phenomenon, entrepreneurship literature traditionally has tended to focus on the creation and management of SMEs within the domestic context (McDougall and Oviatt 2000). More recently, however, an intersection of complementary research paths, between international business and entrepreneurship, has been increasingly evident (Young, Pavlos, and Leo-Paul 2003; McDougall and Oviatt 2000). For example, Autio, Sapienza, and Almeida (2000) found that firms that expand internationally earlier in their life grow faster overall and in foreign markets, as they do not need to overcome a domestic orientation later. Also, Zahra, Ireland, and Hitt (2000) found that a diverse international environment created more opportunities for technical learning for new venture firms.

While such firms may still represent a relatively small proportion of new ventures (Katz, Safranski, and Khan 2003) (unique to firms competing in modern, high-tech industries), there is evidence of firms supporting this born global pattern (Bell et al. 2003). Such industries increasingly demonstrate the importance of networks (Adler and Kwon 2002; Autio 2000; Spencer 2003), emphasize interfirm collaboration, and often are driven by an internationally accepted industry standard (such as a computer oper- 
ating system). Further, these industries often are knowledge-based (Autio, Sapienza, and Almeida 2000; Zahra, Ireland, and Hitt 2000), where such knowledge is unique and the source of competitive advantage. Firms in such industries often are uniquely endowed with highly specific resources that enable them to provide specialized products. As such, the resource-based view and network perspective both can help to explain the growth of international entrepreneurial firms (Young, Pavlos, and Leo-Paul 2003). Similarly, this article uses these perspectives to define when new ventures are likely to exhibit this international entrepreneurial behavior.

Ultimately, resources external to the firm, such as infrastructure, which explain entrepreneurship in general (Van de Ven 1993), seem to be driving international entrepreneurship as well. For this research, infrastructure is considered to be resources that are available beyond the level of the firm; they are not firm specific. However, many high-tech new ventures may be exposed to these external resources, but not all exhibit these "born global" characteristics. Such ventures must still possess firm-specific capabilities that enable them to identify and take advantage of these external resources. To be successful, firms must employ strategies and develop organizational capabilities to integrate and diffuse knowledge (Zahra, Ireland, and Hitt 2000) so that these firms are able to exploit, enhance, or collectively develop this infrastructure. That is, firm strategies and capabilities act as moderators, strengthening the basic relationship of external resources explaining international entrepreneurship; in fact, they are necessary for this relationship. Therefore, explanations for international entrepreneurship may derive from certain cost factors (Swamidass 1993), possession and utilization of unique global resources, and global networks (Adler and Kwon 2002; Spencer, 2003; Young, Pavlos, and Leo-Paul 2003), with firm strategies and capabilities moderating (strengthening) this relationship.

Capabilities are the firm's capacity to accumulate, integrate, and deploy resources to achieve a desired end (Helfat and Raubitschek 2000). First, the competitive international environment today creates challenges and opportunities for firms to distinguish themselves competitively and create value for customers, as customers and competitors are increasingly global in scope. Second, the increasing prevalence of alliances, international networks, global resources, etc. presents vast learning opportunities for firms. Firms must have deliberate strategies to acquire these global resources, disseminate them throughout the organization, and deploy them to achieve competitive advantage. Firms that recognize and respond to these opportunities will succeed internationally.
This study focuses not only on "born global" firms that exhibit international characteristics at an early stage, but firms suddenly internationalizing after a long period of focusing on the domestic market (Bell et al. 2003), as the conditions presented in this model may apply to either phenomena. Finally, for purposes of this study, infrastructure is not a regional issue; it must be available at the global level. That is, contrary to many of the studies of interfirm relations, the primary focus of this article is not on geographic clusters, but on global networks designed to exploit, enhance, or develop specific interfirm resources. Therefore, many of these networks are designed around specific resources, dedicated to their global development, rather than around geographic areas.

\section{Theory and Propositions}

Brown and Eisenhardt (1998) argued that to be successful, firms need to blend the past and the present; that is, to use the old (an established, legitimated framework) and the new (some novel contribution). Even firms marketing innovative new technologies may get into trouble by ignoring the past, such as an accepted standard, demonstrating too much disconnect. Furthermore, firms must strike an ideal balance of internal collaboration within the organization, using a standard technology, sharing a distribution channel, gaining economies of scale in purchasing, cooperating on a one-time product development project, or simply sharing knowledge (Brown and Eisenhardt 1998).

However, small and young ventures must also compete in this environment, which may be problematic. For example, a young firm has a limited past, providing little opportunity to connect to an established track record. Whereas the failure of some incumbent firms may stem from the tendency to rest on successes (connect to the past) and get in a rut, entrepreneurial ventures often fail because they were unable to secure acceptance for their product of the future (Aldrich and Fiol 1994; Brown and Eisenhardt 1998). In this case the new venture may be advised to utilize an accepted platform as its connection to the past. The established framework provides an infrastructure for the new venture from which it can launch its innovation. Second, small firms may have limited opportunities for internal collaboration, and hence may require more external collaboration within a network alliance.

That is, the edge of chaos (Brown and Eisenhardt 1998) characterizing many dynamic industries today require entrepreneurial new ventures to actively utilize infrastructure in order to survive. Entrepreneurship then is actually the collective achievement of many institutions (Van de Ven 1993) as firms improve or add novelties to an existing 
framework. Moreover, as these industries now tend to be global, with the established standards accepted around the world, networks tend to be increasingly global in scope as well. Further, as the resources required to compete in these industries are so specialized and unique, firms must increasingly seek them out on a global basis.

As such, external resources, which increasingly reflect a global scope, are posited in this article as explaining international entrepreneurship, specifically in the case of hightech new ventures. The three factors identified include industry cost factors, unique global resources, and networks. However, only new ventures possessing certain firm-specific capabilities to integrate knowledge (Zahra, Ireland, and Hitt 2000), or learn, will be able to identify and take advantage of such global resources, and therefore, expand internationally.

\section{Cost Factors}

Traditionally, large firms were able to minimize cost through mass production to achieve scale economies and international production to achieve location economies (Dunning 1988; Rugman 1980). However, smaller entrepreneurial firms may not be able to achieve returns to scale or exploit location economies through intrafirm sourcing. They must rely on interfirm collaboration.

That is, many industries face substantial fixed costs, with very low marginal costs of diffusion and imitation, bringing plummeting average costs, and hence, increasing returns to scale. (This is particularly true of the high-technology industries showing such rapid internationalization.) Many firms may expand internationally in order to exploit returns to scale. That is, international expansion may be a necessity for high-technology firms facing substantial R\&D and start-up costs, to be profitable within a rapidly evolving technological environment (Jolly, Alahuhta, and Jeannet 1992). This is especially true if the firm faces a limited niche in the domestic market early in the life cycle, such as would be the case for disruptive technology (Bower and Christensen 1995), where the new technology initially serves a small segment-competing with a wider market for the old sustaining technology.

That is, a technology entrepreneur is generally nichefocused, and a single home market may not be broad enough to support the $\mathrm{R} \& \mathrm{D}$, finance, marketing, and distribution that such a firm would face (Hordes, Clancy, and Baddaley 1995). Furthermore, in this high-tech environment, the cost drivers increasingly are not firm specific. Interfirm sourcing and collaboration (Swamidass 1993) are necessary to achieve cost minimization. The high fixed costs, particularly for high-technology industries, given the limited resources of small entrepreneurial ventures, require interfirm collaboration, while shorter product life cycles further demand cooperation and product extensions deriving from a single design platform (Garud and Kumaraswamy 1995).

Of course, many high-tech ventures likely demonstrate substantial returns to scale, yet relatively few new ventures may still fit the "born global" profile. Therefore, it would appear that firms which are able to maximize technical learning, and which are exposed to such increased learning opportunities from a varied international environment, are therefore more likely to expand their sales internationally (Zahra, Ireland, and Hitt 2000). In knowledge-driven industries, there are vast opportunities to accumulate knowledge about cost management, and much of this knowledge is available internationally. Firms must be able to tap into this knowledge, disseminate it throughout their organization, and develop the capabilities to apply this knowledge to their own organizational processes. Such firms are likely to be exposed to ways of improving efficiency and benefiting from returns to scale, and are able to incorporate it into their own operations. The firms that do accumulate this global knowledge will have an international orientation (Autio, Sapienza, and Almeida 2000), and will be likely to expand sales internationally.

Proposition 1: New high-tech ventures exhibiting tremendous fixed costs will demonstrate greater international operations (sales) than firms that face fewer fixed costs, if such ventures possess organizational capabilities to integrate and apply technical knowledge to exploit returns to scale.

However, increasing returns to scale may be supplanted by a more powerful, and more unique, economic phenomenon: increasing marginal returns. Increasing returns, common to the high-tech and knowledge-based industries, are the tendency for that which is ahead to get further ahead. This stems from high up-front costs with low costs of diffusion, network effects, and technology lock-in (Arthur 1996). An example of this phenomenon would be Netscape, where each additional new user (Beinhocker 1997), and likewise each additional new entrepreneur utilizing the infrastructure, increases the total value of the system. Some firms facing increasing marginal returns would likely pursue international expansion to enhance the effect, wishing to further expand their customer base and "lock in" their technology in those areas that are expected to present great potential future income growth.

In the same sense, network externalities (the increase in user utility as others adopt the product or compatible 
products) (Garud and Kumaraswamy 1995) reflect important phenomena in many high-technology industries today. That is, many technologies today are systemic in nature (Winter 1987), meaning they are embodied in interconnecting multicomponent products (Garud and Kumaraswamy 1995). This requires substantial investment in several complementary technologies and assets (Powell and Brantley 1992; Teece 1987), making it difficult for any one firm to invest in all complementary technologies (Garud and Kumaraswamy 1995).

Garud and Kumaraswamy (1995) and Brown and Eisenhardt (1998) further argue that such factors encourage firms to conform to a common standard or dominant design, to manufacture products that are compatible with the standard technology. For example, a network of firms may establish an open standard, which acts as mechanisms for coordinating the emerging network. As the density of firms manufacturing technological systems that conform to this common standard increases, customers get a wider choice of complementary products, so more customers get onboard. The larger customer base then encourages more firms to adhere to these industry-wide standards, increasing network benefits further. The larger the network, the greater its attraction. Externalities may derive from production as well as consumption (Dunning 1995). This concept refers to a technological network, based upon a common standard. Strategies to form organizational networks, to encourage interfirm collaboration, are addressed below.

In some cases, even large dominant firms, which initially have been reluctant to adopt open standards fearing loss of market share, eventually have become compelled to adhere to an industry-wide standard (Garud and Kumaraswamy 1995). There is no reason to suppose that this network should be limited to a single country. Foreign firms will wish to adopt this established standard as readily as the domestic firms, as will foreign customers. At this point, any firm within the network will face global competitors, partners, as well as customers. Globalization becomes inherent in the infrastructure.

These factors, network externalities as well as industry standardization, have an important effect on what constitutes competitive advantage, and how it is derived. The traditional batch-processing industries have generally demonstrated the importance of firm-level economies of scale and scope, encouraging larger firm size and greater complexity. Large oligopolistic competitors (like MNCs) would compete for greater market share, and would extend their operations internationally, developing their firm-level economies of scale and scope, and learning economies. Organization theory, especially international- ization theory, has been grounded in the same assumptions.

However, the continual innovation seen in many hightech industries limits the potential for scale economies (Garud and Kumaraswamy 1995). Some firm-specific advantages in high-tech industries are slowly being supplanted by the importance of network externalities and complementarity of assets, advantages that go beyond any single firm. These high-tech industries are more likely to require a dominant design and industry standards. This mitigates the advantages of large and established firms, which benefits entrepreneurial ventures, which are then better able to compete with the large MNCs in the global arena.

Of course, recognizing opportunities from network externalities, and developing strategies to exploit these opportunities, is quite a challenge. Firms that are exposed to a variety of technical information from these networks, particularly internationally, and possess organizational capabilities of absorbing this knowledge and applying it to their own processes, will reflect an international orientation, given that these technological networks in high-tech industries are increasingly global in scope. Therefore, such firms are likely to expand sales internationally.

Proposition 2: New high-tech ventures attempting to exploit increasing marginal returns from network externalities will demonstrate greater international operations than firms that do not pursue such network externalities, if they possess organizational capabilities to integrate and apply technical knowledge to exploit marginal returns.

\section{Possession/Utilization of Global Resources}

Unique resources so critical to many high tech industries today are increasingly available on a global scale. Firms may need to draw from the pool of capital, labor, and knowledge (Van de Ven 1993) on a global scale. Furthermore, importing, exporting, sourcing (Kotabe 1992), has been facilitated, leading to a global distribution of many products and services. For example, new financing options, such as countertrade, have facilitated exporting (Carter, Narasimhan, and Vickery 1988; Swamidass 1993). That is, the international trade of goods, services, knowledge, financing, and labor is now commonplace. While many of these resources comprise external resources, firms must possess the capability to effectively utilize and take advantage of these resources.

Perlmutter (1969), looking specifically at multinational corporations, recognized environmental forces leading to a more geocentric orientation, such as technological and 
managerial knowledge increasing in availability around the world, and the integration of international transport and telecommunications systems. These aspects of the growing "international infrastructure" may actually benefit smaller entrepreneurial ventures, as they depend on this infrastructure to survive, more than large corporations. According to Van de Ven (1993), entrepreneurs benefit from infrastructure resource endowments such as scientific/technological research, financing mechanisms, and human resources. Each of these resources is increasingly found on an international scale, and require that firms wishing to exploit them be international in scope as well.

For example, some firms in high-tech, capital, and knowledge-intensive industries increasingly must acquire resources on a global level. Many resources are so specialized that a sufficient endowment simply cannot be found in any single local area. Some Silicon Valley firms, for example, often may need to draw from a pool of human resources on a global scale. A web-based IPO may target various parts of the world to obtain the substantial financial sums that are required. Some biotechnology firms all over the world utilize scientific and technological research pertaining to the Human Genome project for drug development. These infrastructure resource endowments increasingly ignore national borders, and firms exploiting these resources are likely to have a global perspective, and are therefore more likely to sell their products internationally. Of course, only ventures with unique resource endowments and a well-organized process of integrating these diverse global resources will effectively find ways to obtain and utilize this global resource. Firms that effectively incorporate and integrate these global resources into their business operations will possess an international orientation, and therefore will be likely to expand sales internationally.

Proposition 3: New high-tech ventures that draw upon knowledge, financing, or labor on an international scale will demonstrate greater international operations than firms that focus predominantly on domestic sources, if they possess organizational capabilities to identify and integrate these global resources into their operations.

Clearly technological advances in transportation and communication have enabled large corporations to expand their international operations (Perlmutter 1969). This has made intrafirm international trade quite common. However, the advent of new information technologies (Zuboff 1984) also improves interfirm coordination (Fombrun and Astley 1982), thereby reducing transaction costs (Garud and Kumaraswamy 1995).
For example, the Internet, and the way business can be done through this medium, has a global scope and this is part of its appeal. Furthermore, its value is recognized on a global level—by populations the world over, so a firm intending to market its product internationally that utilizes this medium already has an advantage. That is, the Internet has obtained legitimacy at the industry- or technology-level which is recognized globally, meaning firms that depend on this medium are less likely to face the liability of newness (Stinchcombe 1965) that often plagues new organizational forms. That is, industrywide (or networkwide) legitimacy helps to reduce the importance of firm-level legitimacy. This format provides a kind of infrastructure for the start-up companies.

Furthermore, part of the appeal of the product of a firm may be its global scope. In fact, a product, technology, or service in general may be recognized globally, regardless of the specific firm that utilizes it. As argued above, globalization may become inherent in the platform provided by a network, as foreign firms and customers get onboard. In the same sense that a larger network brings greater attractiveness, a more global platform brings greater appeal to customers around the world. That is, more firms using the platform means more customers, and vice-versa. More global firms using the platform means more global customers, and vice-versa.

Of course, global resources are readily available to many new ventures, yet only some have utilized the resources to expand internationally, just as only a few Internet companies have been able to achieve competitive advantage online. Clearly, the firms must possess clear strategies to exploit the resource, and must demonstrate capabilities in integrating this global resource into their operations to achieve competitive advantage. Such firms, oriented toward this important and valued global resource, are likely then to expand sales internationally.

Proposition 4: New high-tech ventures that effectively exploit a global platform (such as a distribution channel) are likely to demonstrate greater international operations than firms that do not utilize such a platform, if they possess organizational capabilities to integrate and exploit this platform.

\section{Network Strategies}

Finally, organizational networks (Adler and Kwon 2002) comprise a critical component of explaining international entrepreneurship today (Wright and Leo-Paul, 2003; Young, Pavlos, and Leo-Paul 2003). A strategy of forming alliances, joint ventures, or cooperative arrangements, may be important for small entrepreneurial ventures to 
develop and utilize interfirm resources. These arrangements may be with suppliers, customers, and competitors, as well as with large established MNCs and/or other hightech entrepreneurs. In fact, networks may be particularly important for knowledge-based industries, which are so applicable in explaining international entrepreneurship (Bell et al. 2003). For example, knowledge-diffusion networks have been found to be critical for firm competitiveness as well as helping to establish industry standards (Spencer 2003).

A new firm usually must form linkages with other firms to establish legitimacy (Aldrich and Fiol 1994) or obtain access to distribution channels. Interfirm associations help to bring skills and financial resources as well as legitimacy and market power (Eisenhardt and Schoonhoven 1996). Therefore, the formation of partnerships and strategic alliances is critical for firms to achieve competitive advantage nowadays. Sometimes, a firm may lack certain resources or skills that they may be able to obtain by forming linkages with other firms. That is, firms may have complementary resources, skills and experiences that would encourage cooperation. For example, Barnett (1990) found that technological standardization (compatibility) and differentiation (complementarity) tended to lead to positive interdependence (mutualism) and hence cooperation among phone companies.

In the same sense, Baum and Singh (1994) found that entrepreneurial firms, depending on the degree of overlap of the niches in which they were founded, might have complementary resources that they can exchange or complement. Furthermore, the complementary skills and resources of established incumbents and entrepreneurial ventures, as well as the necessity of producing an industry dominant design and setting industry standards, may necessitate formation of linkages between established incumbents and entrepreneurial ventures. Entrepreneurs may help to institutionalize their environments through alliances with an established, dominant company in the industry.

These same issues are relevant for a firm wishing to expand internationally. Alliances may be an attractive means of entering foreign markets (Gugler 1992). Small firms can often gain the necessary resources for international activity through cooperative relationships with other firms (Bonaccorsi 1992; McDougall, Shane, and Oviatt 1994). That is, a firm with a skill in a particular technological product or process, but with limited international experience, may form a partnership with a firm or firms that have considerable international experience. International operations carry with it considerable risks, which can be shared by the group or network, thereby reducing the risk for a single firm. The network of firms can bring their collective skills and experiences to the global competitive environment, thereby mitigating the firm-specific advantages that large, established MNCs may have. In this sense, Chang (1995) argued that firms in business groups were more likely to go overseas than independent firms.

These factors make it even more essential for entrepreneurs competing in the global marketplace to form linkages and alliances. A small entrepreneurial venture has limited global resources and less international experience than a large MNC. Hence the sharing of resources as well as risks would help the entrepreneur to compete with the larger incumbents. Furthermore, as the entrepreneurs and MNCs likely possess complementary skills themselves (the former bringing radical new product or process innovation, the latter having considerable experience, access to resources, and legitimacy, on a global scale), they may actually form cooperative partnerships with each other. Such partnerships between the incumbents and entrepreneurs may bring the innovation for the MNC, while securing resources and legitimacy that the new venture requires. Further, when one MNC forms a partnership with a high-tech firm, other MNCs may be forced to form such partnerships as a competitive response.

As a result, if entrepreneurial ventures form linkages with established MNCs early in their life, such as partnerships and strategic alliances, they will likely expand internationally more quickly as a result. Interestingly, Preece, Miles, and Baetz (1999), using a bivariate variable, found no relationship between strategic alliance formation and international activity. Perhaps simply participating in joint ventures and alliances alone is not associated with internationalization, as many new ventures form alliances yet relatively few actually expand internationally immediately. Even engaging in international interfirm cooperation with the intent of selling internationally may not necessarily result in international success for some firms, but rather possessing the organizational capabilities to identify the right international partners (possessing complementary objectives as well as resources), maximize learning throughout the network, and to effectively leverage network resources to achieve competitive advantage globally, will then likely be associated with international activity.

Proposition 5: New high-tech ventures that form linkages with established companies will demonstrate greater international operations than firms that operate alone, if they possess organizational capabilities to absorb and disseminate knowledge across the network. 
In recent years, the combination of two increasingly common trends may also contribute to the born global phenomenon: the increasing use of outsourcing by large corporations and the rapid evolution of new technologies. MNCs increasingly globally outsource many functions to outside firms (Kotabe 1998). Coupled with rapid technological innovation, much of it being developed and marketed by entrepreneurs, this tendency is helping international entrepreneurs to play a greater role in developing and producing new innovative products and processes for the major MNCs. Those firms serving these MNCs must expand to where their clients operate. Miller and Parkhe (1998) recognized the "follow the client" argument for firms expanding internationally. In fact, many small ventures are actually spin-offs of large firms, owe their success primarily to being clients or suppliers to major MNCs, or are part of a keiretsu-like network dominated by a large MNC (Dunning 1995).

The established MNCs have long been internationally focused, giving the entrepreneurial ventures a leg up on international expansion. That is, the global orientation of the MNCs coupled with their increasing inclination to outsource to smaller firms producing new technologies, help to encourage these entrepreneurial firms to operate increasingly on an international scale.

Furthermore, for some industries, the market is viewed on a global basis, not as distinct national boundaries. Many young entrepreneurs have a single global market perspective. Perlmutter (1969) recognized growing world markets and international customers as forces that may encourage greater geocentrism for MNCs. This seems to be the case more and more for entrepreneurial ventures as well, particularly those who possess a clear strategic objective of learning from their clients' international experience and expertise, and develop the organizational capabilities to successfully integrate this knowledge into their own operations. That is, the international orientation of their clients will likely translate into an international orientation for the new venture, likely resulting in increased international sales for that venture.

Proposition 6: New high-tech ventures that serve MNC clients will demonstrate greater international operations than firms serving more single-country customers, if they possess organizational capabilities to integrate and apply their clients' international knowledge.

\section{Performance Implications}

Because of the advantages that infrastructure may provide for entrepreneurial ventures, firm performance (survival and profitability) may depend upon the extent to which these ventures utilize this infrastructure. This article argues that firms that operate as part of a network or platform, whose standards may well likely be accepted globally, will demonstrate greater international operations, if they possess the firm capabilities to learn. It is also argued that firms which demonstrate this global reach will be able to further exploit increasing returns to scale, increasing marginal returns, and global legitimacy. As a result, these firms should demonstrate superior performance. Therefore,

Proposition 7: Younger and newer ventures that expand internationally will demonstrate superior performance than their domestic-only counterparts.

\section{Model}

The purpose of this research has been to develop theory regarding international entrepreneurship. However, empirical studies are needed, so the following section will develop the model, suggest possible operationalizations for the constructs in this article, and provide some suggestions about how this model could be tested.

The independent variable would measure the degree to which the firm utilizes infrastructure (interfirm resources), including cost factors, global resources, and network strategies. Specifically, this variable would include degree of fixed costs, degree of network externalities, utilization of global resources and an external infrastructure (such as the Internet), alliances with MNCs, and major MNCs as clients. Much of this data could be collected via questionnaire, or if available, secondary data reflecting Internet sales, number of alliances, and client information.

Measuring the dependent variable Internationalization would be critical for this study. The "percent of revenue generated overseas" cut-off could distinguish the international firms from domestic only, and would measure intensity. Alternatively, firms that seem to be the most globally oriented (having operations in many distinct countries) as opposed to those that may do business in fewer and a less diverse set of foreign markets. As such, consistent with Preece, Miles, and Baetz (1999) as well as Hout, Porter and Rudden (1982), an empirical study should make a distinction between firms operating internationally from those operating globally. Global diversity (or scope) refers to targeting various distinct market areas, such as Asia, Canada, Europe, Latin America, and the United States. It is important to consider both dimensions, because while it appears that hightechnology ventures are expanding internationally early, it is also the case that managing disparate global operations is an immense undertaking for firms (Bartlett and 


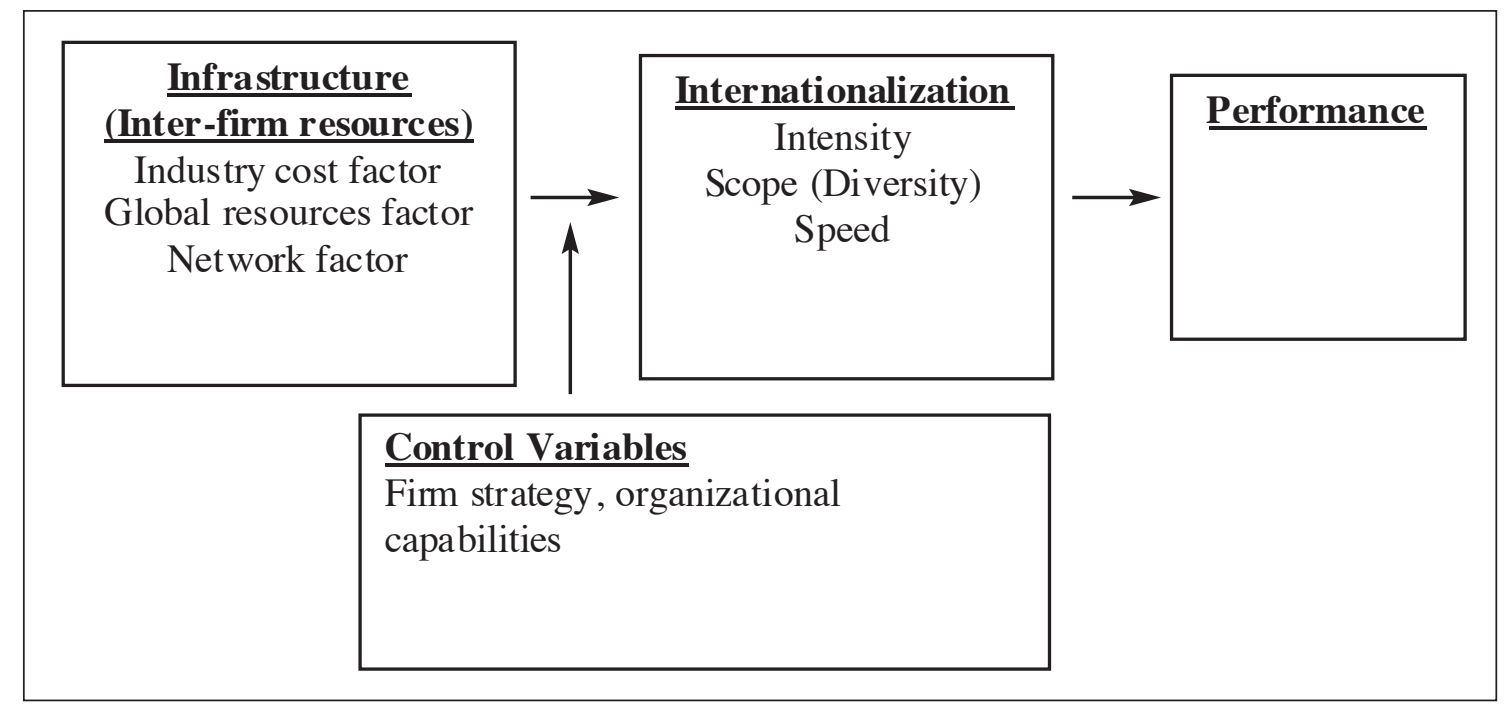

Figure 1. Model of International Entrepreneurship

Ghoshal 1991; Hitt, Tyler, and Park 1995; Prahalad and Doz 1987), but especially for new ventures. A good empirical contribution for such a study could also consider firms that enter into countries that are at various stages of economic development as being more globally diverse. That is, an American firm that enters the Japanese market faces cultural and linguistic diversity. An American firm that enters India faces cultural, linguistic, and degree of market development diversity. The third dimension of Internationalization could then be the annual growth rate of international sales, or speed of internationalization.

Finally, performance is measured in this model. Altogether, the model measures whether interfirm resources lead to increased international operations, then whether that translates into superior performance. The determining factor is whether the firm has a clear strategy and possesses the capabilities to identify and integrate these external resources. The final model is shown in Figure 1.

\section{Conclusions}

To test the above model, an industry would have to be chosen that demonstrates the given constructs. The industry would have to include many firms that rely on traditional as well as emerging infrastructures, such as the Internet. There must be variability along the dimension of the degree to which firms utilize the Internet (or whatever platform) to deliver their product or services as opposed to traditional channels. The industry must also include a large number of entrepreneurial startups that have recently formed, as well as firms that were formed over the last 10 to 20 years or so, to generate variability in firm size and age. The industry should also include substantial international activity as well as variability among the sampled firms along this international dimension. Possible targets where the theories posed in this article may be most applicable include the software industry, publishing industry, music industry (such as radio or sales of CDs), or financial services industries.

The current study has proposed a model of international entrepreneurship and established propositions. The study has drawn from and integrated various literature streams, including infrastructure for entrepreneurship (Van de Ven 1993), global sourcing (Swamidass 1993), and alliance capitalism (Dunning 1995). How these concepts reinforce each other and, as applied to interfirm resources, are important in describing international entrepreneurship, was addressed in this article. Some methodological issues were presented for an empirical research, such as making suggestions about how internationalization should be measured. Hopefully this article has provided some suggestions on how to pursue the theoretical questions posed here as well as sparked some interest in doing so. 


\section{References}

Adler, P.S., and S. Kwon. 2002. Social capital: Prospects for a new concept. Academy of Management Review 27: 17.

Aldrich, H. E., and C. M. Fiol. 1994. Fools rush in? The institutional context of industry creation. Academy of Management Review 19: 645-670.

Arthur, W. B. 1996. Increasing returns and the new world of business. Harvard Business Review July-August: 100-109.

Autio, E. 2000. Growth of technology-based new firms. In Sexton and Landstrom, eds., The Blackwell Handbook of Entrepreneurship. Oxford: Blackwell.

Autio, E., H.J. Sapienza, and J.G. Almeida. 2000. Effects of age at entry, knowledge intensity and imitability on international growth. Academy of Management Journal 43: 925-950.

Barnett, W. P. 1990. The organizational ecology of a technological system. Administrative Science Quarterly 35: 31-60.

Bartlett, C., and S. Ghoshal. 1991. Global strategic management: Impact on the new frontiers of strategy research. Strategic Management Journal 12:5-16.

Baum, J., and J. Singh. 1994. Organizational niches and the dynamics of organizational founding. Organization Science 5: 483-501.

Bell, J., R. McNaughton, S. Young, and D. Crick. 2003. Towards an integrative model of small firm internationalization. Journal of International Entrepreneurship 1: 339-360.

Beinhocker, E.C. 1997. Strategy at the edge of chaos. The McKinsey Quarterly 1: 24-39.

Bonaccorsi, A. 1992. On the relationship between firm size and export intensity. Journal of International Business Studies 23: 605-635.

Bower, J. L., and C. M. Christensen. 1995. Disruptive technologies: Catching the wave. Harvard Business Review, January / February: 43-53.

Brown, Shona L., and Kathleen M. Eisenhardt. 1998. Competing on the edge: Strategy as structured chaos. Boston, MA: Harvard Business School Press.

Carter, Joseph R., Ram Narasimhan, and Shawnee K. Vickery. 1988. Monograph No. 3, International sourcing for manufacturing operations. Waco, TX: Operations Management Association.

Chang, S. J. 1995. International expansion strategy of Japanese firms: Capability building through sequential entry. Academy of Management Journal 38: 383-407.

Dunning, J. H. 1988. The eclectic paradigm of international production: A restatement and some possible extensions. Journal of International Business Studies 19: 1-31.

Dunning, J. H. 1995. Reappraising the eclectic paradigm in an age of alliance capitalism. Journal of International Business Studies 26: 461-492.

Eisenhardt, K., and C. Schoonhoven. 1996. Resource-based view of strategic alliance formation: Strategic and social effects in entrepreneurial firms. Organizational Science 7: 136-150.

Fombrun, C., and W. Astley. 1982. The telecommunications community: An institutional overview, Journal of Communications, 32: 56-68.

Garud, R., and A. Kumaraswamy. 1995. Technological and organizational designs for realizing economies of substitution. Strategic Management Journal 16: 93-109.

Gugler, P. 1992. Building transnational alliances to create competitive advantage. Long Range Planning 25: 90-99.

Helfat, C., and R. Raubitschek. 2000. Product sequencing: Co-evolution of knowledge, capabilities and products. Strategic Management Journal 21: 961-979.

Hitt, M., B. Tyler, and D. Park. 1995. Understanding strategic intent in the global marketplace. Academy of Management Executive 9: 12-19.

Hout, T., M. Porter, and E. Rudden. 1982. How global companies win out. Harvard Business Review 60: 8-108. 
Hordes, M., J. Clancy, and J. Baddaley. 1995. A primer for global start-ups. Academy of Management Executive 9: 7-11.

Johanson, J., and J. Vahlne. 1977. The internationalization process of the firm-A model of knowledge development and increasing foreign market commitment. Journal of International Business Studies 4: 20-29.

Jolly, V., M. Alahuhta, and J. Jeanet. 1992. Challenging the incumbents: How high technology start-ups compete globally. Journal of Strategic Change 1: 71-82.

Katz, J. A., S. R. Safranski, and O. Khan. 2003. Virtual instant global entrepreneurship. Journal of International Entrepreneurship 1: 43-56.

Knight, G. A., and S.T. Cavusgil. 1996. The born global firm: A challenge to traditional internationalization theory. Advances in International Marketing 8: 11-26.

Kotabe, M. 1992. Global sourcing strategy. New York: Quorum Books.

Kotabe, M. 1998. Efficiency vs. effectiveness orientation of global sourcing strategy: Comparison of US and Japanese multinational companies. Academy of Management Executive 12: 107-119.

Linder, S. B. 1961. An essay on trade and transformation. New York: Wiley.

McDougall, P., and B. Oviatt. 2000. International entrepreneurship: The intersection of two research paths. Academy of Management Journal 43: 902-908.

McDougall, P., S. Shane, and B. Oviatt. 1994. Explaining the formation of international new ventures: The limits of theories from international business research. Journal of Business Venturing 9: 469-487.

Miller, S. R., and A. Parkhe. 1998. Patterns in the expansion of US banks' foreign operations. Journal of International Business Studies 29: 359-390.

Oviatt, B., and P. McDougall. 1994. Toward a theory of international new ventures. Journal of International Business Studies 25: 45-64.

Perlmutter, H. 1969. Tortuous evolution of the multinational corporation. Columbia Journal of World Business 3: 9-18.

Posner, M. 1961. International trade and technical change. Oxford Economic Papers 13: 323-41.

Powell, W., and P. Brantley. 1992. Competitive cooperation in biotechnology: Learning through networks. In N. Nohria and R. G. Eccles, eds., Networks and Organizations: Structure, Form and Action. Boston, MA: Harvard Business School Press, pp. 366-394.

Prahalad, C., and T. Doz. 1987. The Multinational Mission. New York: The Free Press.

Preece, Stephen, Miles, Grant, and Mark Baetz. 1999. Explaining the international intensity and global diversity of earlystage technology-based firms. Journal of Business Venturing 14, 3: 259-281.

Rugman, A. 1980. A new theory of the multinational enterprise: Internationalization versus internalization. Columbia Journal of World Business 15: 23-29.

Spencer, J. W. 2003. Global gatekeeping, representation, and network structure: a longitudinal analysis of regional and global knowledge-diffusion networks. Journal of International Business Studies 34: 428.

Stinchcombe, A. L. 1965. Social structure and organizations in J.G. March, ed. Handbook of Organizations. Rand McNally.

Swamidass, Paul M. 1993. Import sourcing dynamics: An integrated perspective. Journal of International Business Studies Forth Quarter: 671-691.

Teece, D. J. 1987. Profiting from technological innovation: Implications for integration, collaboration, licensing and public policy. In D. J. Teece, ed., The Competitive Challenge: Strategies for Industrial Innovation and Renewal. Cambridge, MA: Ballinger, pp. 185-219.

Van de Ven, A. 1993. The development of an infrastructure for entrepreneurship. Journal of Business Venturing 8: 211-230.

Vernon, R., 1966. International investment and international trade in the product cycle. Quarterly Journal of Economics 80: 190-207.

Winter, S. 1987. Knowledge and competence as strategic assets. In D. J. Teece, ed., The Competitive Challenge: Strategies for Industrial Innovation and Renewal. Cambridge, MA: Ballinger, pp. 159-184. 
Wright, R. W., and D. Leo-Paul. 2003. Changing paradigms of international entrepreneurship strategy. Journal of International Entrepreneurship 1: 135-155.

Young, S., D. Pavlos, and D. Leo-Paul. 2003. International entrepreneurship research: What scope for international business theories? Journal of International Entrepreneurship 1: 31-40.

Zahra, S. A., R. D. Ireland, and M. A. Hitt. 2000. International expansion by new venture firms: International diversity, mode of market entry, technological learning, and performance. Academy of Management Journal 43: 925-950.

Zuboff, S. 1984. In the age of the smart machine: The future of work and power. New York: Basic Books.

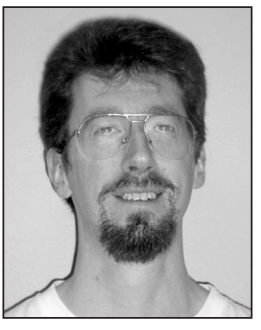

\section{About the Author}

STEPHEN K. CALlaway (scallaway@usi.edu) is an assistant professor at the University of Southern Indiana in Evansville. He received his Ph.D. from Temple University in May 2003. He has presented papers and co-authored papers published in proceedings at several conferences including Midwest Academy of Management in 2003 and 2001, Babson College-Kauffman Foundation Entrepreneurship Research Conference in 1999, and USASBE/SBIDA in 2001. His research interests include emerging technologies, international entrepreneurship, and corporate entrepreneurship. In 2001, he was the recipient of the Best Graduate Student Paper award at the Midwest Academy of Management. 